\title{
Obesity and cardiovascular disease
}

\section{Antonio Pérez Pérez*, Juan Ybarra Muñoz, Vicente Blay Cortés and Pedro de Pablos Velasco}

\author{
Servicio de Endocrinología y Nutrición, Hospital de la Santa Creu i Sant Pau, S. Antoni Ma Claret 167, \\ 08025 Barcelona
}

Submitted December 2006: Accepted April 2007

\begin{abstract}
Background: The prevalence of obesity has reached epidemic proportions, and in terms of the extent of its negative impact on the health has been compared to those of tobacco and alcohol. One of the first medical consequences of obesity to be recognised was cardiovascular disease (CVD). Obesity, particularly abdominal obesity, predisposes a person to a number of other cardiovascular risk factors, and is an independent predictor of clinical CVD including coronary death, coronary heart disease, heart failure and stroke.

Materials and methods: A Medline search using the following keywords (obesity, cardiovascular disease, body mass index, cardiovascular risk factors, type 2 diabetes, metabolic syndrome) was performed looking for high impact factor English-written references.

Results: Ninety-nine $(N=99)$ relevant articles published in the last 15 years were selected and commented. As detailed throughout the text, current therapies available for weight management can improve or prevent many of these obesityrelated risk factors for CVD. However, there is some controversy as to whether weight loss is beneficial for health, and large clinical outcome trials such as the Look-AHEAD (Action for Health in Diabetes) trial or the SCOUT (Sibutramine Cardiovascular Outcomes Trial) study are currently ongoing.

Discussion: In the present review, we summarise the effects of obesity as well as the efficacy of weight-loss interventions on cardiovascular risk factors and CVD.
\end{abstract}

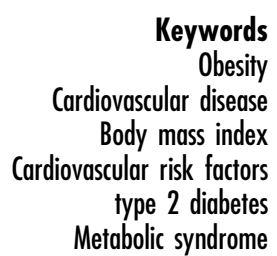

The increased prevalence of obesity in the past few years has been the focus of literally thousands of articles in the scientific and lay press as well as in the newspapers. The problem has been called an epidemic and compared to the harmful effects of tobacco and alcohol in terms of the extent of its negative impact on the health of the population $^{1-9}$. Furthermore, as the full extent of the relatively rapid increase in weight in the population has been recognised, the significant involvement of children and adolescents in this change has become obvious. It is interesting to consider why the increase in obesity in the population over the past two decades has suddenly been recognised as so potentially harmful. The publication of the National Health and Nutrition Examination Survey (NHANES) data from 1999-2000² was key in bringing this problem to the attention of health professionals and the public. In addition, the excellent review by Kopelman ${ }^{3}$ published in 2000 highlighted many aspects about obesity that were underappreciated, and also stressed obesity as a medical problem with deleterious effects on health. Overweight and obesity are associated with the morbidity and mortality of many health conditions, such as coronary heart disease (CHD), type 2 diabetes, gall bladder disease, ischaemic stroke, osteoporosis, sleep apnoea and some types of cancers ${ }^{1,6-9}$. Obesity is also associated with a substantial reduction in life expectancy. Recent data from the United States suggest that a severe level of obesity (body mass index (BMI) $>45 \mathrm{~kg} \mathrm{~m}^{-2}$ ) during early adulthood (aged 20-30 years) may reduce a man's life expectancy by up to 13 years and a woman's by up to 8 years?

The objectives of this review are to summarise the effects of obesity and the effects of weight-loss interventions on cardiovascular risk factors and cardiovascular disease (CVD).

\section{Classification and prevalence of obesity}

Obesity is characterised by an excess of adipose tissue. There are, however, different types of fat and different locations for fat in the body $3,10-13$. Visceral fat has been shown to be a better indicator of obesity-associated disorders than the amount of total fat. The most commonly used measurement for determining obesity is the BMI, which is calculated as the weight $(\mathrm{kg}) /$ height $\left(\mathrm{m}^{2}\right)$ or as the weight $(\mathrm{lb}) /$ height $\left(\mathrm{in}^{2}\right) \times 703$. Although there are 
some limitations to measuring obesity by the BMI, it is an index that provides a measurable estimate of body fat and is related to the risk of complications associated with obesity ${ }^{11}$. According to the National Institute of Health (NIH) ${ }^{14}$ and the World Health Organisation (WHO) documents, the normal range for the BMI is $18.5-24.9 \mathrm{~kg} \mathrm{~m}^{-2}$, while $25.0-29.9 \mathrm{~kg} \mathrm{~m}^{-2}$ is class (or grade) 1 overweight, $30.0-39.9 \mathrm{~kg} \mathrm{~m}^{-2}$ is class (or grade) 2 overweight and $\geq 40.0 \mathrm{~kg} \mathrm{~m}^{-2}$ is class (or grade) 3 overweight. There are alternative measurements of obesity that are useful ${ }^{12}$. Waist circumference alone has been shown to correlate with obesity-related disorders. In fact, this measurement relates closely to the BMI and does reasonably accurately reflect the proportion of intra-abdominal body fat compared to subcutaneous fat and its disease implications ${ }^{10}$. Other methods include underwater weighing (hydrodensitometry), dilution methods (hydrometry), dual energy X-ray absorptiometry (DXA), skin fold measurements by calipers, bioimpedance analysis and imaging methods such as computed tomography (CT) and magnetic resonance imaging (MRI). However, they are too costly and complex to use for individual patient's assessment or large-scale epidemiologic studies ${ }^{13}$.

Applying the BMI to epidemiological surveys ${ }^{2}$ has indicated that approximately $65 \%$ of US adults are overweight (35\%) (BMI $\geq 25 \mathrm{~kg} \mathrm{~m}^{-2}$ ) or obese $\left(\mathrm{BMI} \geq 30 \mathrm{~kg} \mathrm{~m}^{-2}\right)$ (30\%). The greatest increases in the past two decades have been in the highest BMI category (extreme or morbid obesity) i.e. BMI $\geq 40 \mathrm{~kg} \mathrm{~m}^{-2}$. The prevalence of extreme obesity is approximately $4.7 \%$ of US adults (up from $0.8 \%$ in 1960). When one translates these percentages to absolute numbers the scope of the problem becomes obvious ${ }^{15}$. The prevalence and trends in overweight and obesity among US children and adolescents were measured in 1976-1980, 1988-1994 and 1999-2000 and were updated between 1999 and $2002^{16,17}$. The prevalence of overweight was 15-16\% among 6 to 19-yearolds in 1999-2000, which represented a marked increase compared to similar measurements made in 1988-1994 (10.5-11.3\%). Among the youngest group (2 to 5 years old) the overweight prevalence increased from $7.2 \%$ to $10.4 \%$ over the decade. Finally, it is worth noting that data from the Behavioural Risk Factor Surveillance System (BRFSS), which is a cross-sectional telephone survey of non-institutionalised adults, conducted between the years 1986 to 2000, indicated that the prevalence of a BMI of $40 \mathrm{~kg} \mathrm{~m}^{-2}$ or greater quadrupled and the prevalence of a BMI of $50 \mathrm{~kg} \mathrm{~m}^{-2}$ or greater increased five-fold in adults $^{5,12}$.

\section{Health consequences of obesity}

The health consequences of obesity are many and there is a dose-response relationship between the degree of obesity and the risk of morbidity and mortality from CVD and other conditions. Although there have been studies indicating that increasing body weight is associated with a higher mortality ${ }^{13-15,18,19}$, this relationship remained controversial until relatively recently. The excellent study by Calle et al. ${ }^{19}$ has reinforced the conclusions reached in many earlier analyses that indicate that there is a curvilinear relationship in which the risk of death is increased among those with the highest or lowest weights. The same study showed that the lowest rates of death from all causes were found at BMI's between 23.5 and $24.9 \mathrm{~kg} \mathrm{~m}^{-2}$ in men and between 22.0 and 23.4 in women. Death rates from all causes (cardiovascular, cancer or other diseases) increased throughout the range of moderate and severe overweight for both men and women in all age groups. It is of interest that the risk was greater for whites than for blacks, particularly black women ${ }^{19}$. According to recent $\mathrm{NIH}$ statistics, obese individuals have a $50 \%$ to $100 \%$ increased risk of death from all causes compared to normal weight individuals (BMI $20-25 \mathrm{~kg} \mathrm{~m}^{-2}$ ). Most of the increased risk is due to CVDs. Life expectancy of a moderately obese person could be shortened by $2-5$ years, while morbidly obese men could reduce their life expectancy by almost 13 years ${ }^{15}$.

\section{Obesity and otber cardiovascular risk factors}

Obesity predisposes a person to a number of cardiovascular risk factors, including impaired glucose tolerance and type 2 diabetes, hypertension, dyslipidaemia and sleep apnoea.

There is good evidence of an association between excess body weight, especially when located in the abdominal region, and type 2 diabetes. The high prevalence of diabetes in overweight or obese individuals is of particular concern, especially in young adults. As examples, among patients diagnosed with type 2 (noninsulin-dependent) diabetes, $67 \%$ have a BMI $\geq 27 \mathrm{~kg} \mathrm{~m}^{-2}$, and $46 \%$ have a $\mathrm{BMI} \geq 30 \mathrm{~kg} \mathrm{~m}^{-215}$. About $70 \%$ of diabetes risk in the US can be attributed to excess weight. In the Nurses Cohort Study, the risk of diabetes increased five-fold for those with a BMI of $25 \mathrm{~kg} \mathrm{~m}^{-2}$, 28-fold for those with a BMI of $30 \mathrm{~kg} \mathrm{~m}^{-2}$ and 93-fold for those with a BMI of $35 \mathrm{~kg} \mathrm{~m}^{-2}$ or greater compared with women with a BMI of less than $21 \mathrm{~kg} \mathrm{~m}^{-2} 20,21$. Similar patterns of increasing prevalence of diabetes with increasing weight have been noted in men. As was mentioned earlier, a waist circumference of $>40$ in increases the risk of diabetes 3-5-fold even after controlling for BMI. In children and adolescents type 2 diabetes has been estimated to account for between $8 \%$ and $45 \%$ of all new cases of diabetes $^{22}$. Moreover, the potential for the development of renal failure, impaired vision, cardiovascular and cerebrovascular disease and the neurological complications of diabetes after 15-20 years, when these individuals are young adults, indicates the incredibly serious implications of this epidemic. 
There is good evidence of an association between excess body weight and high blood pressure. The ageadjusted prevalence of hypertension in overweight US adults is $22.1 \%$ for men with BMI $25-27 \mathrm{~kg} \mathrm{~m}^{-2}, 27 \%$ for men with BMI $27-30 \mathrm{~kg} \mathrm{~m}^{-2}, 27.7 \%$ for women with BMI $25-27 \mathrm{~kg} \mathrm{~m}^{-2}$ and $32.7 \%$ for women with BMI $27-30 \mathrm{~kg} \mathrm{~m}^{-2}$. These compare with the prevalence of hypertension of approximately $15 \%$ in normal weight men and women ${ }^{15}$. The effect of hypertension together with other deleterious haemodynamic effects on the heart has resulted in an increase in the development of congestive cardiac failure (CCF) best documented in the Framingham Heart Study. It is of interest that body weight was directly related to the development of CCF independent of other traditional risk factors $^{23}$.

Obesity has a strong effect on lipoprotein metabolism, regardless of ethnic groups ${ }^{24-26}$. Increased weight is a determinant of higher levels of triglycerides, elevated LDL-C, and low HDL-C. Conversely, weight loss is associated with a healthier lipoprotein profile in both genders. There is evidence that central adiposity compared with total adiposity is more positively associated with increased triglyceride level, lower HDL cholesterol and less positively associated with LDL cholesterol. Total adiposity is more strongly associated with LDL cholesterol.

Breathing problems during sleep are a common consequence of obesity. For example, it is not uncommon for some obese men to have low oxygen saturation during REM sleep while their awake arterial gases are normal $^{27}$. A minority of individuals progress to the sleep apnoea syndrome ${ }^{28}$. In the Swedish Obesity Study, over $50 \%$ of the men and $33 \%$ of the women with a BMI $>$ $35 \mathrm{~kg} \mathrm{~m}^{-2}$ reported snoring and sleep apnoea ${ }^{29}$. These changes during sleep seem to carry an increased risk of myocardial infarction and stroke ${ }^{30}$.

\section{Obesity and CVD}

Prospective studies that have reported follow-up data over 2-4 decades have documented that obesity is an independent predictor of clinical CVD, including coronary death, CHD, heart failure and stroke in white and non-white populations ${ }^{23,31-53}$. One of the earliest analyses of the Framingham Heart Study was reported by Hubert et $a l^{23}$ After 26 years of follow-up, they concluded that obesity, measured as the ratio of actual weight to desirable weight (MRW), was a significant independent predictor of CVD, including CHD, coronary death and congestive heart failure in both men and women, and stroke in women after adjustment for risk factors. After 44 years of follow-up, Wilson et al. ${ }^{31}$ showed that CVD risk (including angina, myocardial infarction, CHD or stroke) was higher among overweight obese men and obese women after adjustment for age, smoking, high blood pressure, high cholesterol and diabetes. The association was not significant among overweight women. In the
Nurses' Health Study, ${ }^{32}$ after 16 years of follow-up, the risk of death from CVD was significantly greater among women with a BMI $\geq 27 \mathrm{~kg} \mathrm{~m}^{-2}$ compared with the risk among women with a BMI $<19 \mathrm{~kg} \mathrm{~m}^{-2}$. Analysis of results from the American Cancer Society's Cancer Prevention Study $\mathrm{I}^{34}$ involving 324135 participants showed that excess body weight increased the risk of death from CVD in healthy white adults aged 30-74 years followed up over a period of 12 years. Above 74 years, however, the risk of death was not significant for either men or women. Similar results were obtained by Baik et al. ${ }^{35}$ in the Health Professionals Follow-up Study. CVD mortality among obese $\left(\mathrm{BMI} \geq 30 \mathrm{~kg} \mathrm{~m}^{-2}\right.$ ) men aged less than 65 years was significantly greater after accounting for other risk factors including smoking compared with those with a $\mathrm{BMI}<23 \mathrm{~kg} \mathrm{~m}^{-2}$. Among men 65 years or older, there was no significant relationship between BMI and risk of CVD mortality. Thus, there is good evidence of an association between overweight and obesity and CVD incidence among young to middle-aged men and women but not among older people. The reduced risk at older ages may, however, be mediated by the duration of excess bodyweight ${ }^{23,37,38}$. Finally, there is moderate evidence of an association between abdominal obesity and risk of CVD, particularly among older men ${ }^{46-51}$.

\section{Abdominal obesity and CVD: the metabolic syndrome}

The presence of abdominal obesity, due to excess visceral fat, is associated with both an increased risk of developing $\mathrm{CVD}^{54,55}$ and an increased risk of metabolic syndrome, which includes a greater risk of developing type 2 diabetes $^{56}$ and attendant cardiometabolic disturbances ${ }^{57}$.

Metabolic syndrome has been widely studied in adults. Its prevalence in adults is approximately $20 \%$ of individuals $\geq 20$ years of age and $40 \%$ of the population $>40$ years of age ${ }^{58}$. Taking into account its high predictive value for the development of type 2 diabetes and CVD, it is of great concern that this syndrome is being diagnosed in adolescents in increasing numbers. Thus Duncan et al. ${ }^{59}$ have shown a significant increase in this syndrome in adolescents over the past decade (4.2\% in 1988-1992 to $6.4 \%$ in 1999-2000). Moreover, the syndrome was found in $32.1 \%$ of overweight adolescents (BMI $\geq 95$ th percentile for age and sex).

There is ongoing debate regarding the acceptance of the various metabolic syndrome definitions and guidelines worldwide ${ }^{60}$, but the other definitions of metabolic syndrome are very similar ${ }^{61,62}$. In the clinical setting, waist circumference is commonly used as a surrogate marker of abdominal fat ${ }^{63}$, since measurement of waist circumference is more practical than BMI and has been found to correlate closely with total abdominal fat mass ${ }^{64}$. 
In addition, waist circumference is strongly associated with all-cause mortality in middle-aged adults ${ }^{65}$.

In the Nurses' Health Study, Rexrode et al. ${ }^{51}$ concluded that the waist-to-hip ratio (WHR) and waist circumference are independently associated with CHD risk after controlling for BMI and other cardiac risk factors. Women in the highest quintile of WHR or waist circumference were about 2.5 times more likely to develop CHD than women in the lowest quintile and the association was more pronounced in women younger than 60 years. Accordingly, results from case-control studies showed that abdominal fat was associated with an increased risk of stroke. In the Northern Manhattan Stroke Study, involving 576 stroke cases, those with a WHR greater than or equal to the median had an OR of 3.0 for ischaemic stroke ${ }^{48}$. The association occurred in men and women and in all race-ethnic groups; it was a stronger predictor of stroke than BMI, and had a greater effect among younger persons. In a British case-control study involving men and women aged 35-74 years, Shinton et $a l^{49}$ found that excess body fat, in particular abdominal fat, increased the risk of stroke, although cigarette smoking presented a greater risk than abdominal fat alone. In a large study by Rimm et al. ${ }^{50}$ involving 29122 men aged 40-75 years, it was found that BMI and WHR were associated with an increased risk of CHD. Among younger men, obesity is a strong risk factor for CHD, independent of fat distribution, whereas for older men, measures of fat distribution may be a better predictor of coronary disease. Finally, the INTERHEART study was designed to assess the importance of nine risk factors on CHD risk, as measured by a first episode of myocardial infarction ${ }^{66}$. These factors were current or former smoking, history of diabetes or hypertension, abdominal obesity, combined psychosocial stressors, irregular consumption of fruits and vegetables, no alcohol intake, avoidance of any regular exercise and raised plasma lipids. All nine risk factors represented a population attributable risk (PAR) of $90.4 \%$, accounting for most of the risk of acute myocardial infarction in the study population. After adjustment for age, sex and geographic region, abnormal lipids had the highest PAR in men (49.5\%) and women (47.1\%). Abdominal obesity contributed 19.7\% (men) and $18.7 \%$ (women) to this risk, and had a similar odds ratio to hypertension, especially in men (odds ratios of 2.24 and 2.32, respectively).

Although there is evidence of an association between abdominal obesity and increased risk of CVD, current debate concerns how visceral adiposity contributes to the development of CVD. Although the main function of adipocytes is regarded as storage and release of energy, several factors secreted by adipocytes have regulatory roles in metabolism and exert vascular effects ${ }^{67}$. The possibility of a direct link between endothelial dysfunction and insulin resistance, mediated via adipokine action on the vascular endothelium, is a topical issue ${ }^{68}$. The role of these adipokines in the pathogenesis of obesity, particularly abdominal obesity and insulin resistance, has created much controversy ${ }^{69-72}$. In summary, proinflammatory adipokines play a causal role in the development of insulin resistance and pathologies associated with increased cardiovascular risk ${ }^{73}$. Obesity has also been linked with chronic low-grade inflammation ${ }^{67,73}$, as mediated by interleukin (IL)-6 and tumour necrosis factor- $\alpha$, which may also contribute to the atherosclerotic process $^{74}$. Furthermore, IL-6 has been suggested to increase hepatic triglyceride secretion, which in turn may lead to insulin resistance ${ }^{71}$.

\section{Effects of weight loss on CVD}

Obesity predisposes a person to a number of cardiovascular risk factors, including hypertension, dyslipidaemia and impaired glucose tolerance and, in overweight and obese subjects, weight loss can improve or prevent many of these obesity-related risk factors for $\mathrm{CVD}^{75,76}$. However, there is some controversy as to whether weight loss is beneficial for health.

Effective treatments exist for overweight/obese patients and a combination of therapies provides the best results. Current therapies available for weight management include lifestyle intervention, physical activity, pharmacotherapy and surgery.

Both clinical prospective and intervention studies have shown that sustained moderate weight loss (10\%) achieved through lifestyle intervention are effective for the prevention/treatment of hypertension, diabetes and dyslipidaemia ${ }^{75,76}$. In a recent systematic review, weight loss of $10 \mathrm{~kg}$ was associated with a fall in diastolic blood pressure of $3.6 \mathrm{mmHg}$, and a weight loss of $10 \%$ was associated with a fall in systolic blood pressure of $6.1 \mathrm{mmHg}^{77,78}$. The benefit of modest weight loss achieved by lifestyle intervention on diabetes prevention was demonstrated in the Diabetes Prevention Program ${ }^{79}$. After an average of 3.2 years, lifestyle intervention reduced the incidence of diabetes by $58 \%$ and Metformin reduced the incidence by $31 \%$ when compared with placebo. In addition, lifestyle intervention was accompanied by an important reduction in other traditional cardiovascular risk factors (reduction in hypertension, triglycerides, atherogenic LDL particles, and an elevation in HDL-cholesterol concentration) and non-traditional cardiovascular risk factors relative to both placebo and to a lesser degree to Metformin ${ }^{80,81}$. Similar findings were reported in the Chinese Da Qing IGT and Diabetes Study ${ }^{82}$ and the Finnish Diabetes Prevention Study ${ }^{83}$. In addition, in patients with type 2 diabetes modest weight loss is associated with reductions in HbA1c of $1.1 \%$, fasting blood glucose of $1.6 \mathrm{mmoll}^{-1}$, triglycerides of $0.5 \mathrm{mmol}^{-1}$ and with an increase in HDL-cholesterol of $0.1 \mathrm{mmol}^{-184}$.

Weight management is also associated with an improvement of the lipid profile of obese subjects. In general, a 5-10\% weight loss can produce a reduction in 
LDL cholesterol of $15 \%$ and triglycerides of $20-30 \%$ with an increase in HDL cholesterol of $8-10 \%{ }^{76}$. Furthermore, a systematic review has shown that a fall of $0.23 \mathrm{mmoll}^{-1}$ in total cholesterol may be expected for a weight loss of $10 \mathrm{~kg}$ in a person suffering from obesity or overweight ${ }^{85}$. Finally, there is evidence that modest weight loss decreases levels of several haemostatic factors associated with obesity and the development of CVD, and markers of vascular inflammation, such as C-reactive protein and ILs 6, 7 and $18^{86,87}$. Overall, these findings suggest that even moderate weight loss with lifestyle intervention can improve risk factors for CVD in overweight and obese subjects.

The two drugs currently approved for obesity treatment (sibutramine and orlistat), and the new class of drugs that antagonise central and peripheral CB1 cannabinoid receptors (rimonabant), produce similar degrees of weight loss and weight loss maintenance. In placebocontrolled studies, the percentage of patients achieving $5 \%$ weight loss at 1 year is broadly similar to sibutramine, orlistat0 and rimonabant ${ }^{88-92}$.

Pharmacologically induced weight loss has a beneficial impact on a number of cardiovascular risk factors, such as diabetes, blood pressure and dyslipidaemia, and in some cases these effects appear to be over and above that explained by weight loss. Repeated observations have suggested that weight loss with sibutramine is associated with a specific increase in HDL-cholesterol. A metaanalysis of studies in which patients received long-term sibutramine treatment show that, regardless of the degree of weight loss, there is a marked increased effect on raising HDL-cholesterol, suggesting that there may be an independent effect, while the effects of orlistat are most marked with regard to LDL-cholesterol ${ }^{93}$. Similarly, in type 2 diabetes patients, at equivalent weight loss, the use of orlistat resulted in greater improvement in free fatty acids levels and insulin sensitivity than placebo ${ }^{94}$. Finally, results from the RIO-Europe study suggest that about half of the rise in HDL-cholesterol and about half of the fall in triglycerides cannot be accounted for by weight loss alone, suggesting possible independent effects ${ }^{90}$.

Weight-loss surgery is the most effective therapy available for people who are extremely obese. It reverses, ameliorates or eliminates major cardiovascular risk factors, including diabetes, hyperlipidaemia, hypertension and other lipid disturbances ${ }^{95}$.

Despite the risks of overweight and obesity are being generally well accepted and the beneficial effects of weight loss on a number of cardiovascular risk factors being proved, there is some controversy as to whether weight loss is beneficial because some observational epidemiological studies have associated weight loss with increased mortality $^{96}$. A likely explanation lies in the fact that the studies did not distinguish between intentional and unintentional weight loss. Interestingly, the few studies that have addressed this issue show benefit from weight loss on mortality ${ }^{97}$. Other difficulty surrounding the relationship between intentional weight loss and mortality is that success with behaviour modification and currently available medications in achieving sustained weight loss is quite limited and surgical procedures, such as gastric bypass, are effective for sustained weight loss, but are used as a last resort for patients with a BMI $>40 \mathrm{~kg} \mathrm{~m}^{-2}$ and those with multiple obesity-related complications.

Thus, longer term, well-controlled studies are needed to define accurately the benefits of weight loss on mortality and other 'hard' clinical endpoints. Two large-scale randomised clinical trials are now under way and should provide important information on the effects of non-surgical obesity treatment on cardiovascular morbidity and mortality. Look AHEAD (Action for Health in Diabetes) ${ }^{98}$ is a large outcome study that is currently assessing the effect of weight loss produced by an intensive lifestyle intervention delivered over 4 years on cardiovascular events and mortality in obese diabetic patients. This programme is compared to a control condition involving a program of diabetes support and education. The primary basis for the comparison is the incidence of serious cardiovascular events. Other outcomes, including CVD risk factors, diabetes-related metabolic factors and complications, and the cost-effectiveness of the intensive intervention are also studied. The other trial is the SCOUT trial (Sibutramine Cardiovascular Outcomes Trial) ${ }^{99}$. This is a double-blinded, randomised, placebo-controlled, parallel group, global multi-centre study with a singleblinded sibutramine lead-in period. It involves a large group of overweight and obese subjects at high risk for CVD and has been designed to determine the impact of weight loss with sibutramine on cardiovascular endpoints. The primary endpoint of the trial will include a composite of myocardial infarction, stroke, resuscitated cardiac arrest and cardiovascular death.

\section{Acknowledgements}

Sources of funding: ISCIII-RETIC RD06, PI052099 and PI051540 funded this work.

Conflict of interest declaration: None of the authors had any conflict of interest.

Authorship contributions: All the authors (A.P.P., J.Y.M., V.B.C., P.P.V.) declare that they participated sufficiently in the work to take full and public responsibility for its content.

\section{References}

1 World Health Organization (WHO). Obesity: Preventing and Managing the Global Epidemic. Report of a WHO Consultation. WHO Technical Report Series 894. Geneva: WHO, 2000.

2 Flegal KM, Carroll MD, Ogden CL, Johnson CL. Prevalence and trends in obesity among US adults, 1999-2000. Journal 
of the American Medical Association 2002; 288: 1723-7.

3 Kopelman PG. Obesity as a medical problem. Nature 2000; 404: 635-43.

4 Kuczmarski RJ, Flegal KM, Campbell SM, Johnson CL. Increasing prevalence of overweight among US adults: the National Health and Nutrition Examination Surveys, 1960-1991. Journal of the American Medical Association 1994; 272: 205-11.

5 Mokdad AH, Serdula MK, Dietz WH, Serdula MK, Bowman BA, Marks JS, et al. The spread of the obesity epidemic in the United States. 1991-1998. Journal of the American Medical Association 1999; 282: 1519-22.

6 Rubenstein AH. Obesity: a modern epidemic. Transactions of The American Clinical and Climatological Association 2005; 116: 103-11.

7 Gregg EW, Cheng YJ, Cadwell BL, Imperatore G, Williams $\mathrm{DE}$, Flegal KM, et al. Secular trends in cardiovascular disease risk factors according to body mass index in US adults. Journal of the American Medical Association 2005; 293(15): 1868-74.

8 Flegal KM, Graubard BI, Williamson DF, Gail MH. Excess deaths associated with underweight, overweight, and obesity. Journal of the American Medical Association 2005; 293(15): 1861-7.

9 Fontaine KR, Redden DT, Wang C, Westfall AO, Allison DB. Years of life lost due to obesity. Journal of the American Medical Association 2003; 289: 187-93.

10 Han TS, van Leer EM, Seidell C, Lean MEJ. Waist circumference action levels in the identification of cardiovascular risk factors: prevalence study in a random sample. British Medical Journal 1995; 311: 1401-5.

11 Kushner RF, Roth JL. Assessment of the obese patient. Endocrinology and Metabolism Clinics 2003; 32(4): 915-933.

12 Mokdad AH, Bowman BA, Ford ES, Bowman BA, Vijnicor F, Marks JS, et al. The continuing epidemics of obesity and diabetes in the United States. Journal of the American Medical Association 2001; 285: 1195-200.

13 Calle EE, Kaaks R. Overweight, obesity and cancer: epidemiological evidence and proposed mechanisms. Nature Reviews 2004; 4: 579-91.

14 National Heart, Lung and Blood Institute. Clinical guidelines on the identification, evaluation, and treatment of overweight and obesity in adults. The evidence report. Obesity Research 1998; 6(Suppl. 2): 51S-210S.

15 NIDDK Weight-control Information Center: US Department of Health and Human Services, National Institutes of Health. 2003. Statistics Related to Overweight and Obesity. NIH Publication No. 03-4158.

16 Ogden CL, Flegal KM, Carroll MD, Johnson CL. Prevalence and trends in overweight among US children and adolescents, 1999-2000. Journal of the American Medical Association 2002; 288: 1728-32.

17 Hedley AA, Ogden CL, Johnson CL, Carroll MD, Curtin LR, Flegal KM. Prevalence of overweight and obesity among US children, adolescents, and adults, 1999-2002. Journal of the American Medical Association 2004; 291: 2847-50.

18 Lew EA, Garfinkel L. Variations in mortality by weight among 750,000 men and women. Journal of Chronic Diseases 1979; 32: 563-76.

19 Calle EE, Thun MJ, Petrelli JM, Rodriguez C, Heath CW. Body-mass index and mortality in a prospective cohort of US adults. New England Journal of Medicine 1999; 341: 1097-105.

20 Colditz GA, Willett WC, Rotnitsky A, Manson JE. Weight gain as a risk factor for clinical diabetes in women. Annals of Internal Medicine 1995; 122: 481-6.

21 Lean MEJ, Hans TS, Seidell JC. Impairment of health and quality life in people with large waist circumference. Lancet 1998; 351: 853-6.
22 Dietz WH. Overweight in childhood adolescence. New England Journal of Medicine 2004; 350: 855-8.

23 Hubert HB, Feinleib M, McNamara PM, Castelli WP. Obesity as an independent risk factor for cardiovascular disease: 26-year follow-up of participants in the Framingham heart study. Circulation 1983; 67: 968-77.

24 Ferrara A, Barrett-Connor E, Shan J. Total, LDL, and HDL cholesterol decrease with age in older men and women. The Rancho Bernardo Study 1984-1994. Circulation 1997; 96: 37-43.

25 Owen CG, Whincup PH, Odoki K, Gilg JA, Cook DG. Birth weight and blood cholesterol level: a study in adolescents and systematic review. Pediatrics 2003; 111(5): 1081-9.

26 Despres J-P. Dyslipidaemia and obesity. Clinical Endocrinology and Metabolism 1994; 8(3): 629-60.

27 Kopelman PG. Sleep apnoea and hypoventilation in obesity. International Journal of Obesity 1992; 16(Suppl. 2): $537-42$.

28 Rochester DF, Eaton U. Current concepts in the pathogenesis of the obesity-hypoventilation syndrome. Mechanical and circulatory factors. American Journal of Medicine 1994; 57: 402-20.

29 Grunstein RR, Stenlof K, Hedner J, Sjostrom L. Impact of obstructive apnoea and sleepiness on metabolic and cardiovascular risk factors in the Swedish Obese Subjects (SOS) Study. International Journal of Obesity and Related Metabolic Disorders 1995; 19: 410-18.

30 Palomaki H, Partinen M, Erkinjuntti T, Kaste M. Snoring, sleep apnoea syndrome and stroke. Neurology 1992; 42(Suppl. 6): 75-81.

31 Wilson PW, D'Agostino RB, Sullivan L, Parise H, Kannel WB. Overweight and obesity as determinants of cardiovascular risk. The Framingham experience. Archives of Internal Medicine 2002; 162: 1867-72.

32 Manson JE, Willett WC, Stampfer MJ, Colditz GA, Hunter DJ, Hankinson SE, et al. Body weight and mortality among women. New England Journal of Medicine 1995; 333: 677-85.

33 Kannel W, D'Agostino R, Cobb J. Effect of weight on cardiovascular disease. American Journal of Clinical Nutrition 1996; 63(3): S419-21.

34 Stevens J, Cai J, Pamuk E. The effect of age on the association between body mass index and mortality. New England Journal of Medicine 1998; 338(1): 1-7.

35 Baik I, Ascherio A, Rimm EB, Giovannucci E, Spiegelman D, Stampfer MJ, et al. Adiposity and mortality in men. American Journal of Epidemiology 2000; 152(3): 264-71.

36 Singh P, Lindsted K. Body mass and 26-year risk of mortality from specific diseases among women who never smoked. Epidemiology 1998; 9: 246-54.

37 Harris T, Cook F, Garrison R. Body mass index and mortality among non-smoking older persons. The Framingham Heart Study. Journal of the American Medical Association 1998; 259(10): 1520-4.

38 Spataro JA, Dyer AR, Stamler J, Shekelle RB, Greenlund K, Garside D. Measures of adiposity and coronary heart disease mortality in the Chicago Western Electric Company study. Journal of Clinical Epidemiology 1996; 49(8): 849-57.

39 Kenchaiah S, Evans JC, Levy D, Wilson PW, Benjamin EJ, Larson MG, et al. Obesity and the risk of heart failure. New England Journal of Medicine 2002; 347(5): 305-13.

40 He J, Ogden LG, Bazzano LA, Vupputuri S, Loria C, Whelton PK. Risk factors for congestive heart failure in US men and women. NHANES I epidemiologic follow-up study. Archives of Internal Medicine 2001; 161: 996-1002.

41 Kurth T, Gaziano JM, Berger K, Kase CS, Rexrode KM, Cook $\mathrm{NR}$, et al. Body mass index and the risk of stroke in men. Archives of Internal Medicine 2002; 162: 2557-62. 
42 Field AE, Coakley EH, Must A, Spadano JL, Laird N, Dietz $\mathrm{WH}$, et al. Impact of overweight on the risk of developing common chronic diseases during a 10-year period. Archives of Internal Medicine 2001; 161: 1581-6.

43 Harmsen P, Rosengren A, Tsipogianni A, Wilhelmsen L. Risk factors for stroke in middle-aged men in Goteborg, Sweden. Stroke 1990; 21: 223-9.

44 Walker SP, Rimm EB, Ascherio A, Kawachi I, Stampfer MJ, Willett WC. Body size and fat distribution as predictors of stroke among US men. American Journal of Epidemiology 1996; 144: 1143-50.

45 Rexrode $\mathrm{KM}$, Hennekens $\mathrm{CH}$, Willett WC, Colditz GA, Stampfer MJ, Rich-Edwards JW, et al. A prospective study of body mass index, weight change, and risk of stroke in women. Journal of the American Medical Association 1997; 277: 1539-45.

46 Shaper A, Wannamethee S, Walker M. Body weight: implications for the prevention of coronary heart disease, stroke and diabetes mellitus in a cohort study of middle aged men. British Medical Journal 1997; 314: 1311-17.

47 Kannel WB, Cupples LA, Ramaswami R, Stokes 3rd J, Kreger BE, Higgins M. Regional obesity and risk of cardiovascular disease: the Framingham study. Journal of Clinical Epidemiology 1991; 44: 183-90.

48 Suk SH, Sacco RL, Boden-Albala B, Cheun JF, Pittman JG, Elkind MS, Northern Manhattan Stroke Study. Abdominal obesity and risk of ischemic stroke. Stroke 2003; 34: 1586-92.

49 Shinton R, Sagar G, Beevers G. Body fat and stroke: unmasking the hazards of overweight and obesity. Journal of Epidemiology and Community Health 1995; 49: 259-64.

50 Rimm EB, Stampfer MJ, Giovannucci E, Ascherio A, Spiegelman D, Colditz GA, et al. Body size and fat distribution as predictors of coronary heart disease among middle-aged and older US men. American Journal of Epidemiology 1995; 141: 1117-27.

51 Rexrode KM, Carey VJ, Hennekens CH, Walters EE, Colditz GA, Stampfer MJ, et al. Abdominal adiposity and coronary heart disease in women. Journal of the American Medical Association 1998; 280: 1843-8.

52 Adams-Campbell LL, Pensiton RL, Kim KS, Mensah E. Body mass index and coronary artery disease in African-Americans. Obesity Research 1995; 3: 215-19.

53 Zhou B, Wu Y, Yang J, Li Y, Zhang H, Zhao L. Overweight is an independent risk factor for cardiovascular disease in Chinese populations. Obesity Reviews 2002; 3: 147-56.

54 Emery EM, Schmid TL, Kahn HS, Filozof PP. A review of the association between abdominal fat distribution, health outcome measures, and modifiable risk factors. American Journal of Health Promotion 1993; 7: 342-53.

55 Despres JP, Lemieux I, Prud'homme D. Treatment of obesity: need to focus on high risk abdominally obese patients. British Medical Journal 2001; 322: 716-20.

56 Eckel RH, Grundy SM, Zimmet PZ. The metabolic syndrome. Lancet 2005; 365: 1415-28.

57 Stumvoll M, Goldstein BJ, van Haeften TW. Type 2 diabetes: principles of pathogenesis and therapy. Lancet 2005; 365: $1333-46$

58 Kip KE, Marroquin OC, Kelley DE, Johnson DB, Kelsey SF, Shaw LJ, et al. Clinical importance of obesity versus the metabolic syndrome in cardiovascular risk in women. A report from the women's ischemia syndrome evaluation (WISE) study. Circulation 2004; 109: 706-13.

59 Duncan GE, Li SM, Zhou XH. Prevalence and trends of a metabolic syndrome phenotype among US adolescents, 1999-2000. Diabetes Care 2004; 27: 2438-43.

60 Reaven GM. The metabolic syndrome: requiescat in pace. Clinical Chemistry 2005; 51: 931-8.

61 International Diabetes Federation. The IDF worldwide definition of the metabolic syndrome. Launched 14 April 2005. Accessible via http://www.idf.org/home/index. cfm?unode $=32 \mathrm{EF} 2063-\mathrm{B} 966-468$ F928CA5682A4E3910 (accessed June 2006).

62 Alberti KG, Zimmet P, Shaw J, IDF Epidemiology Task Force Consensus Group. The metabolic syndrome - a new worldwide definition. Lancet 2005; 366: 1059-62.

63 Klein S. The case of visceral fat: argument for the defense. The Journal of Clinical Investigation 2004; 113: 1530-2.

64 Pouliot MC, Despres JP, Lemieux S, Moorjani S, Bouchard C, Tremblay A, et al. Waist circumference and abdominal sagittal diameter: best simple anthropometric indexes of abdominal visceral adipose tissue accumulation and related cardiovascular risk in men and women. American Journal of Cardiology 1994; 73: 460-8.

65 Bigaard J, Frederiksen K, Tjonneland A, Thomsen BL, Overvad K, Heitmann BL, et al. Waist and hip circumferences and all-cause mortality: usefulness of the waist-to-hip ratio? International Journal of Obesity and Related Metabolic Disorders 2004; 28: 741-7.

66 Yusuf S, Hawken S, Ounpuu S, Dans T, Avezum A, Lanas F, et al. INTERHEART Study Investigators. Effect of potentially modifiable risk factors associated with myocardial infarction in 52 countries (the INTERHEART study): case-control study. Lancet 2004; 364: 937-52.

67 Perry C, Sattar N, Petrie J. Adipose tissue: passive sumper active pump. Diabetes and Vascular Disease Research 2001; 1: $110-14$.

68 Ritchie SA, Ewart MA, Perry CG, Connell JM, Salt IP. The role of insulin and the adipocytokines in regulation of vascular endothelial function. Clinical Science (London) 2004; 107: 519-32.

69 Lau DC, Dhillon B, Yan H, Szmitko PE, Verma S. Adipokines: molecular links between obesity and atherosclerosis. American Journal of Physiology. Heart and Circulatory Physiology 2005; 288: H2031-41.

70 Arner P. Insulin resistance in Type 2 diabetes - role of the adipokines. Current Molecular Medicine 2005; 5: 333-9.

71 Wajchenberg BL. Subcutaneous and visceral adipose tissue: their relation to the metabolic syndrome. Endocrine Reviews 2000; 21: 697-738.

72 Fasshauer M, Paschke R. Regulation of adipocytokines and insulin resistance. Diabetologia 2003; 46: 1594-603.

73 Trayhurn P. The biology of obesity. Proceedings of the Nutrition Society 2005; 64: 31-8.

74 Hansson GK. Inflammation, atherosclerosis, and coronary artery disease. New England Journal of Medicine 2005; 352: $1685-95$.

75 Orzano AJ, Scott JG. Diagnosis and treatment of obesity in adults: an applied evidence-based review. The Journal of the American Board of Family Practice 2004; 17: 359-69.

76 Van Gaal LF, Mertens IL, Ballaux D. What is the relationship between risk factor reduction and degree of weight loss? European Heart Journal Supplements 2000; 7(Suppl. L): L21-6.

77 Avenell A, Broom J, Brown TJ, Poobalan A, Aucott L, Stearns SC, et al. Systematic review of the long-term effects and economic consequences of treatments for obesity and implications for health improvement. Health technology assessment 2004; 8: iii-iv, 1-182.

78 Mertens IL, Van Gaal LF. Overweight, obesity, and blood pressure: the effects of modest weight reduction. Obesity Research 2000; 8: 270-8.

79 Knowler WC, Barrett-Connor E, Fowler SE, Hamman RF, Lachin JM, Walker EA, et al. Diabetes Prevention Program Research Group. Reduction in the incidence of Type 2 diabetes with lifestyle intervention or metformin. New England Journal of Medicine 2002; 346: 393-403.

80 Ratner R, Goldberg R, Haffner S, Marcovina S, Orchard T, Fowler S, et al. Diabetes Prevention Program Research Group. Impact of intensive lifestyle and metformin therapy on cardiovascular disease risk factors in the diabetes prevention program. Diabetes Care 2005; 28: 888-94. 
81 Haffner S, Temprosa M, Crandall J, Fowler S, Goldberg R, Horton E, et al. Diabetes Prevention Program Research Group. Intensive lifestyle intervention or metformin on inflammation and coagulation in participants with impaired glucose tolerance. Diabetes 2005; 54: 1566-72.

82 Pan XR, Li GW, Hu YH, Wang JX, Yang WY, An ZX, et al. Effects of diet and exercise in preventing NIDDM in people with impaired glucose tolerance. The Da Qing IGT and Diabetes Study. Diabetes Care 1997; 20: 537-44.

83 Tuomilehto J, Lindstrom J, Eriksson JG, Valle TT, Hamalainen $\mathrm{H}$, Ilanne-Parikka $\mathrm{P}$, et al. Finnish Diabetes Prevention Study Group. Prevention of Type 2 diabetes mellitus by changes in lifestyle among subjects with impaired glucose tolerance. New England Journal of Medicine 2001; 344: $1343-50$.

84 Wing RR, Koeske R, Epstein LH, Nowalk MP, Gooding W, Becker D, et al. Long-term effects of modest weight loss in Type II diabetic patients. Archives of Internal Medicine 1987; 147: 1749-53.

85 Poobalan A, Aucott L, Smith WC, Avenell A, Jung R, Broom J, et al. Effects of weight loss in overweight/obese individuals and long-term lipid outcomes - a systematic review. Obesity Reviews 2004; 5: 43-50.

86 Esposito K, Pontillo A, Di Palo C, Giugliano G, Masella M, Marfella $\mathrm{R}$, et al. Effect of weight loss and lifestyle changes on vascular inflammatory markers in obese women: a randomized trial. Journal of the American Medical Association 2003; 289: 1799-804.

87 Haffner S, Temprosa M, Crandall J, Fowler S, Goldberg R, Horton E, et al. Diabetes Prevention Program Research Group. Intensive lifestyle intervention or Metformin on inflammation and coagulation in participants with impaired glucose tolerance. Diabetes 2005; 54: 1566-72.

88 Torgerson JS, Hauptman J, Boldrin MN, Sjostrom L. XENical in the prevention of diabetes in obese subjects (XENDOS) study: a randomized study of orlistat as an adjunct to lifestyle changes for the prevention of Type 2 diabetes in obese patients. Diabetes Care 2004; 27: 155-61.

89 James WP, Astrup A, Finer N, Hilsted J, Kopelman P, Rossner $S$, et al. Effect of sibutramine on weight maintenance after weight loss: a randomised trial. STORM Study Group. Sibutramine Trial of Obesity Reduction and Maintenance. Lancet 2000; 356: 2119-25.
90 Van Gaal LF, Rissanen AM, Scheen AJ, Ziegler O, Rossner S, for the RIO-Europe Study Group. Effects of the cannabinoid-1 receptor blocker rimonabant on weight reduction and cardiovascular risk factors in overweight patients: 1year experience from the RIO-Europe study. Lancet 2005; 365: 1389-97.

91 Chong E. Weight loss produced by sibutramine: a metaanalysis. International Journal of Obesity and Related Metabolic Disorders 2001; 25(Suppl. 2): S104-9.

92 O'Meara S, Riemsma R, Shirran L, Mather L, ter Riet G. A rapid and systematic review of the clinical effectiveness and cost-effectiveness of orlistat in the management of obesity. Health Technology Assessment 2001; 5: 1-81.

93 Finer N. Does pharmacologically induced weight loss improve cardiovascular outcome? Impact of anti-obesity agents on cardiovascular risk factors. European Heart Journal Supplements 2005; 7(Suppl. L): L32-8.

94 Kelley DE, Kuller LH, McKolanis TM, Harper P, Mancino J, Kalhan S. Effects of moderate weight loss and orlistat on insulin resistance, regional adiposity, and fatty acids in Type 2 diabetes. Diabetes Care 2004; 27: 33-40.

95 Sjostrom L, Lindroos AK, Peltonen M, Torgerson J, Bouchard C, Carlsson B, et al. Swedish Obese Subjects Study Scientific Group. Lifestyle, diabetes, and cardiovascular risk factors 10 years after bariatric surgery. New England Journal of Medicine 2004; 351: 2683-93.

96 Higgins M, D'Agostino R, Kannel W, Cobb J, Pinsky J. Benefits and adverse effects of weight loss. Observations from the Framingham Study. Annals of Internal Medicine 1993; 119: 758-63.

97 Williamson DF, Thompson TJ, Thun M, Flanders D, Pamuk E, Byers T. Intentional weight loss and mortality among overweight individuals with diabetes. Diabetes Care 2000; 23: 1499-504.

98 Ryan DH, Espeland MA, Foster GD, Haffner SM, Hubbard VS, Johnson KC, et al. Look AHEAD Research Group. Look AHEAD (Action for Health in Diabetes): design and methods for a clinical trial of weight loss for the prevention of cardiovascular disease in Type 2 diabetes. Controlled Clinical Trials 2003; 24: 610-28.

99 James WPT. The SCOUT study: risk-benefit profile of sibutramine in overweight high risk cardiovascular patients. European Heart Journal Supplements 2005; 7: L44-8. 